\title{
China, the emerging economic power: options and repercussions for Pak-US relations
}

\author{
Hafeez Ullah Khan ${ }^{1}$ iD
}

(c) Springer Nature Limited 2020

\begin{abstract}
Washington established relations with Pakistan immediately after the independence when Moscow was diplomatically avoided by Pakistan elite policymakers to opt for one of the superpowers as a need for the Cold War. The article aims to analyses Beijing as an emerging economic power with special reference to Pak-US relations. During and after the Cold War period both the USA and Pakistan have close relations to deter communist expansionism in South Asia and Central Asia but post 9/11 when the US decided to overthrow the Taliban government in Afghanistan, Pakistan aligned its policies and strategies with Washington. Despite Pakistan's huge sacrifices and loss of life and economic suffering, the US still doubts Pakistan's intentions. In this backdrop, Pakistan tilted wholeheartedly toward its all-weather friend China for its diplomatic moral, political, and military support.
\end{abstract}

Keywords BRI · CPEC · Cold War · Pakistan · Afghanistan · Emergent China · USA $\cdot$ Pak-US relations $\cdot$ India-China relations

\section{Introduction}

Napoleon once said, "China is a sleeping giant. Let her lie and sleep, for when she awakens she will astonish the world." The twenty-first century witnessed that the sleeping giant woke and ready to become a competitor of the US in economic, diplomatic, and political influence at the same time threatening the US hegemony in the different regions of the world. From the past several years, China's Market Economy has grown to an unmatched scale with double-digit development in gross domestic product. The spotlight has shifted to the Chinese leadership, who are playing a more dynamic part in regional and international politics (Lee 2007). China's growing GDP, her economy and military advancements, etc., indicate that she is now

Hafeez Ullah Khan

hafeez@awkum.edu.pk

1 Department of Political Science, Abdul Wali Khan University Mardan, House \# 13, Major

Road, F-11/3, Islamabad, Pakistan 
emerging as a new superpower, rather emerged as a superpower. Numbers of factors facilitated China in becoming a superpower, such as the Equity Joint Venture Law of 1979 and Deng Xiaoping's opening-up-to the world strategy. Resultantly this led the international companies and the foreign investment in China, which completely revolutionized the Chinese internal economic setting that shifted from conventional and out-modeled to a vibrant and contemporary one. The other imperative factor in China's rise is its strategy, which is the five years plan. This state strategy has steadily boomed the Chinese economy in addition to several targeted industries, which were identified by the State in the FYP. The third feature of this progress of China is its labor force, which is a true national asset. Regardless of whether the labor is cheapest or costly, but China has utilized this workforce to the utmost. Within three decades, the estimated, over 786 million-man power has turned China into the world's factory. Last but not the least, the overseas Chinese namely Huáqiáo (Chinese citizens residing abroad) and Huáyì (Chinese descent living abroad, not considering their citizenship) are the fourth major aspect behind the unexpected Chinese economic growth. A statement by the World Bank's Migration and Development Brief reveals that the diasporas of China have been pouring revenues into China in the form of remittances estimated \$64 billion in 2017 (Zohra 2018). These aforementioned factors led China toward the pinnacle of success, together with numerous other factors, which helped China to rise and shine. This Chinese swift progress in the fields of trade and industry has been recognized by the whole world at the same time. Western observers see the rise of China as an economic power with apprehension and dismay and reckon that the economic might of China will gradually make her powerful politically and militarily, which will be a threat to the existing political and economic world order, which is presently under the control of the West and to simply put it, specifically by the United States (Khalid and Khan 2018b). Hence, "The China threat" and "containing China" are becoming much-debated topics now (Zhu 2001). The US perceives it as a threat and is busy devising new strategies to contain China, for which it is developing strategic relationships with India. This US-India factor is to create fissures in Pak-China relations or contain both China and Pakistan through direct support of India. This policy will hurt the Pak-US relations. 


\section{China's meteoric rise on world scene}

\section{Growing GDP}

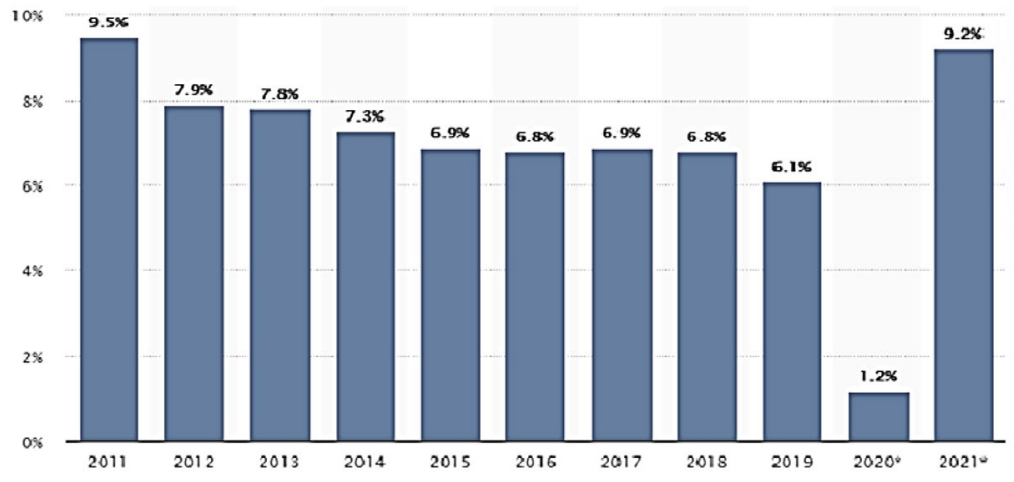

\section{Source: Statista.com}

This graph indicates the projected growth rate of Chinese GDP, which is constant with a slight dip on the negative side. The growth rate of GDP of China was the highest in 2011 but the projected IMF rates show a constant decrease to 5.6 in 2023. The economic strength of a country is signified through the current gross domestic product, because it refers to the overall worth of the entire products and services manufactured in a country per annum.

China's historical GDP

\begin{tabular}{clccccccc}
\hline Year & GDP & \multicolumn{9}{c}{ Real growth \% } & \multicolumn{1}{l}{ GDPPC } & & Real growth \% \\
\cline { 2 - 9 } & CNY & USD & PPP (int'1 \$) & & & & & \\
\hline 2019 & $99,086.50$ & $14,363.48$ & $28,335.53$ & 6.1 & 70,892 & 10,276 & 20,273 & 5.7 \\
2018 & $91,928.11$ & $13,891.88$ & $26,274.93$ & 6.7 & 66,006 & 9975 & 18,866 & 6.2 \\
2017 & $83,203.59$ & $12,323.17$ & $23,633.36$ & 6.9 & 60,014 & 8889 & 17,047 & 6.3 \\
2016 & $74,639.51$ & $11,237.00$ & $21,312.18$ & 6.8 & 54,139 & 8151 & 15,459 & 6.2 \\
2015 & $68,885.82$ & $11,059.95$ & $19,452.68$ & 7.0 & 50,237 & 8066 & 14,186 & 6.5 \\
2014 & $64,356.31$ & $10,476.71$ & $18,175.64$ & 7.4 & 47,173 & 7679 & 13,323 & 6.9 \\
2013 & $59,296.32$ & 9574.42 & $16,612.87$ & 7.8 & 43,684 & 7054 & 12,239 & 7.3 \\
2012 & $53,858.00$ & 8531.96 & $15,179.39$ & 7.9 & 39,874 & 6317 & 11,238 & 7.4 \\
2011 & $48,794.02$ & 7554.66 & $13,919.28$ & 9.6 & 36,302 & 5621 & 10,356 & 9.1 \\
2010 & $41,211.93$ & 6087.88 & $12,445.47$ & 10.6 & 30,808 & 4551 & 9304 & 10.1 \\
2009 & $34,851.77$ & 5102.00 & $11,045.47$ & 9.4 & 26,180 & 3833 & 8297 & 8.9 \\
2008 & $31,924.46$ & 4596.69 & $10,037.24$ & 9.7 & 24,100 & 3470 & 7577 & 9.1 \\
2007 & $27,009.23$ & 3551.98 & 8945.53 & 14.2 & 20,494 & 2695 & 6788 & 13.6 \\
2006 & $21,943.85$ & 2752.68 & 7608.82 & 12.7 & 16,738 & 2100 & 5804 & 12.1 \\
\hline
\end{tabular}




\begin{tabular}{lllllllll}
\hline Year & GDP & \multicolumn{3}{c}{ Real growth \% } & GDPPC & & Real growth \% \\
\cline { 2 - 9 } & CNY & USD & PPP (int'1 \$) & & & & \\
\hline 2005 & $18,731.89$ & 2286.69 & 6539.32 & 11.4 & 14,368 & 1754 & 5016 & 10.7 \\
2004 & $16,184.02$ & 1955.35 & 5719.54 & 10.1 & 12,487 & 1509 & 4413 & 9.4 \\
2003 & $13,742.20$ & 1660.29 & 5051.72 & 10.0 & 10,666 & 1289 & 3921 & 9.3 \\
2002 & $12,171.74$ & 1470.55 & 4515.91 & 9.1 & 9506 & 1148 & 3527 & 8.4 \\
2001 & $11,086.31$ & 1339.41 & 4078.10 & 8.3 & 8717 & 1053 & 3207 & 7.5 \\
\hline
\end{tabular}

World Economic Outlook Database October 2019

China, in 2017, was the second state having the largest gross domestic products throughout the globe, after the US with a GDP of roughly19.5 trillion\$. China's GDP has considerably increased during the previous decade. Analysis of the GDP allocation throughout the trade and industry segments reveals a steady reallocation from an industrial production-dependent economy toward a services-dependent economy and the service industry surpassing the industrial zone in GDP input. The balance of trade is another measurement of the economic assessment, which calculates the connection between imports and exports of a country. In 2017, due to an industrialized and trade production economy, China has reached a trade surplus in the preceding years with a sum trade stability of around 421.4 billion dollars (Statista 2019). Therefore, the economic growth of China cannot go unnoticed. According to the World Bank, in 2018 China's GDP was 13.61 trillion\$, and the US has 20.54 trillion\$ GDP (World Bank n.d). The progress in the real gross domestic product (GDP) in China amounted to about 6.1 percent in 2019. According to the IMF forecast, the GDP of China will be expected to decline in 2020 due to the Coronavirus pandemic and will increase again in 2021.

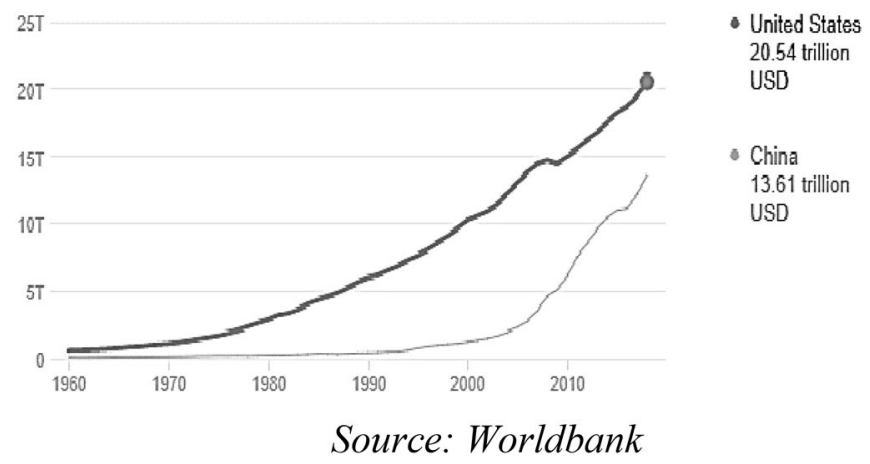

\section{Military budget expansion}

A state's possible military competence can be easily measured through its military budget and expenditure. Two states' defense capabilities can be estimated by drawing a comparison between their bulks of armed forces budget they have 
allocated over a while. Every region has its particular military trends and evaluating a state's defense budget can help to indicate and identifying the crucial political incidents that augmented the military budget provision. In addition to this, the size of the defense budget highlights the significance of a nation's army as compared to the rest of the other national organs. For this reason, the evaluation of gross military expenditures plus the bulk of the defense budget of a nation is significant in a state's GDP (gross domestic product) and general budget.

Thus, total defense expenditure plus the mass of overall defense funds as compared to the country's general budget and its gross domestic product (GDP) is important (China power 2020). China has also increased her defense in recent years, and on March, 5, 2018, the Chinese Finance Minister suggested a funds raise of $8.1 \%$ in contrast to the earlier years nailing the 2018 budget of China at 1.107 trillion Yuan (\$174.6 billion). Though an 8.1 percent rise in 2018 is a little increase for the last couple of years, in 2016 and 2017 the defense funds grew by 7.6 percent and 7 percent, respectively. The exact sum of China's defense spending is extensively argued about.

Chinese Figures on Military Expenditure

\begin{tabular}{|c|c|c|c|c|c|c|c|}
\hline \multirow[t]{2}{*}{ Year } & \multicolumn{2}{|l|}{ Personnel } & \multicolumn{2}{|c|}{ Training and sustainment } & \multicolumn{2}{|l|}{ Equipment } & \multirow{2}{*}{$\begin{array}{l}\text { Total } \\
\text { Billions of } \\
\text { Renminbi }\end{array}$} \\
\hline & $\begin{array}{l}\text { Billions of } \\
\text { Renminbi }\end{array}$ & Share of total & $\begin{array}{l}\text { Billions of } \\
\text { Renminbi }\end{array}$ & Share of total & $\begin{array}{l}\text { Billions of } \\
\text { Renminbi }\end{array}$ & Share of total & \\
\hline 2010 & 185.9 & 35 & 170.0 & 32 & 177.4 & 33 & 533.3 \\
\hline 2011 & 206.5 & 34 & 189.9 & 32 & 206.3 & 34 & 602.8 \\
\hline 2012 & 195.6 & 29 & 233.0 & 35 & 240.6 & 36 & 669.2 \\
\hline 2013 & 200.2 & 27 & 270.0 & 36 & 270.9 & 37 & 741.1 \\
\hline 2014 & 237.2 & 29 & 268.0 & 32 & 323.7 & 39 & 829.0 \\
\hline 2015 & 281.9 & 31 & 261.5 & 29 & 365.4 & 40 & 908.8 \\
\hline 2016 & 306.0 & 31 & 267.0 & 27 & 403.6 & 41 & 976.6 \\
\hline 2017 & 321.1 & 31 & 293.4 & 28 & 428.8 & 41 & 1043.2 \\
\hline
\end{tabular}

Source: State Council Information Office of the People's Republic of China

The certified numbers issued by the administration of China fix the 2017 defense budget of the country at 1.044 trillion Yuan and 2016's defense budget at 955 billion Yuan. Stockholm International Peace Research Institute (SIPRI) states that the Chinese budget in 2017 figured at $\$ 228$ billion and 2016 approximate at $\$ 216$ billion, while the rest of the institutes declare varying estimates. For example, the US Department of Defense puts the 2016 military budget above $\$ 180$ billion, while the International Institute for Strategic Studies (IISS) gives the figure of $\$ 197$ billion (China Power 2020). According to SIPRI China again increased its military expenditure and spent 261 billion\$ in 2019 (McCarthy 2020). 


\section{China's Defense Spending}

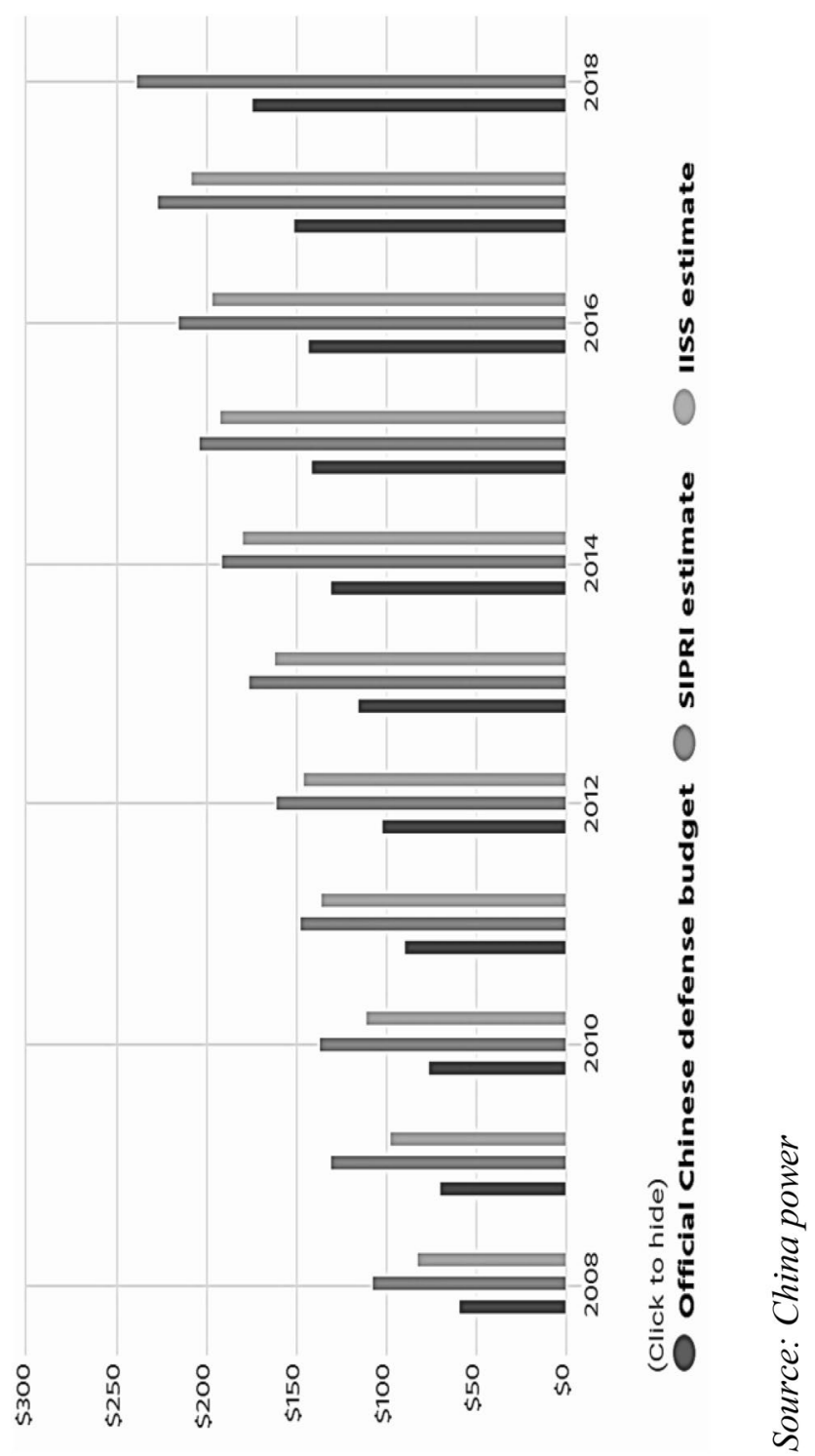


Despite Beijing having increased in the defense budget, it could not overcome or match Washington's military spending. The US keeps increasing the funding of the armed forces every year and in 2019, its defense budget funding reached $\$ 750$ billion as announced by US President Donald Trump. Also, the US Navy rules the water of the world and leaves China far behind in its global access and logistical abilities. But the US War college professor, Andrew Erickson says that China is promptly improving and gaining on her rival, America through scientific advancement and manufacturing new vessels. In words of Andrew Erickson, "No one has presided over this level of Chinese military development in Chinese history before Xi Jinping," (CNN 2019).

\section{Military Expenditure by Country (in US\$ billions) 2018}

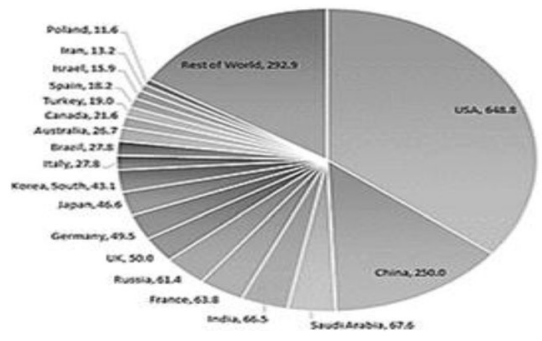

Source: SIPRI

\section{China's regional influence and international organizations}

During the Maoist era, Beijing was very rigid toward international institutions as it comprehended western-oriented and served western and American interests but when Deng took control of China, Beijing actively involved in international organizations. Therefore, the Chinese government has involved itself progressively into international organizations more than ever before. The growing role of China in all assortments of international organizations tells the tale of China's growth. China is not only becoming part of international organizations but establishing new mediums and organizations. This is firstly because the phenomenon of globalization has closely linked China with other independent countries, secondly because it has engaged in international organizations, China has undoubtedly gained the advantage and it was not possible for China to grow without being part of international organizations and thirdly because the rise of China has created needs for headship and involvement in other states. For that reason China must accept international liability. Presently, regarding the role in international organizations, China is facing a colossal challenge in advancing the multi-polarization of the global structure and addressing grave international problems like climate change, poverty, non-proliferation, poverty, and global warming (Xie 2011). 
China is actively participating in the majority of international and regional organizations. China along with Russia rules the Shanghai Cooperation Organization, which has prospered quite speedily since its commencement and has become one of the most important of regional organizations. There is no disagreement with its worth which remains under great discussion in scholarly spheres and global think tanks. The SCO member countries occupy roughly $30.189 \mathrm{~m}$ square kilometers of territory, which makes it almost three-fifth of the continent of Eurasia. Other than this, China is one of the high-flying and lasting members of the UN Security Council as well. China also takes an full part in the major global and regional nuclear non-proliferation and weapon control organizations, such as IAEA, C.D, ASEAN Regional Forum (ARF), etc. (Zhang and Austin 2013).

\section{BRI as Beijing's power show}

Chinese president, XI Jinping, during his visit of Indonesia and Kazakhstan in 2013, announced the "Silk Road Economic Belt" or BRI and the "21st Century Maritime Silk Road." BRI has multiple targets such as improvement of outward investment, growth of new markets, the abolition of congestion, renewal of regional economy, and making the RMB significant in international markets. That is why the BRI was considered a response to the US "rebalancing strategy" (Khan and Khalid 2018a, b).

The world's second-largest economy of China is mainly due to the assortment of overseas trade and the rise in outward assets in search of new markets to safeguard her concerns and creating a fresh milieu where she can flourish in economic activities. The BRI also is a means to form a region, which is led by the Chinese economy (Ohashi 2019). This Project of the BRI has also helped China to grow economically in the region and on the world map (Fig. 1).

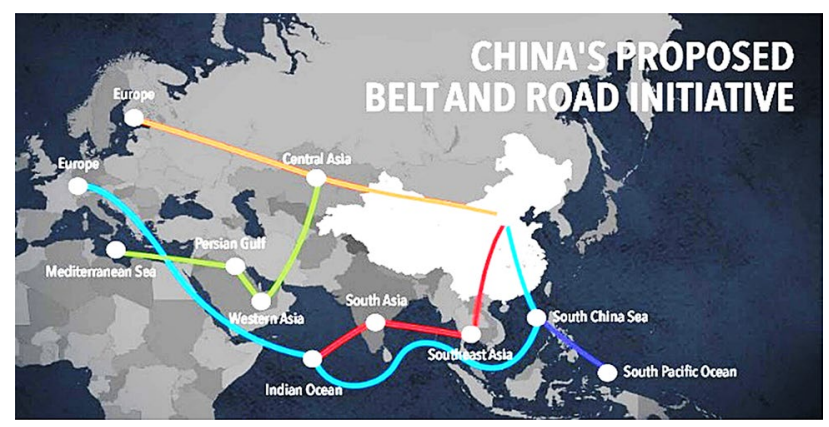

Fig. 1 Source: The Jakarta Post 


\section{China role: Myth or reality/assertion of George Freidman in the book "the next hundred years"}

George Friedman, who founded STRATFOR, a paramount private intelligence and forecasting firm in his inspiring book talks about "the future." He suggests a logical and profoundly understandable prediction of the changes bearing in mind that global society is at the dawn of a fresh epoch. Supported by a personal meticulous analysis and investigation, he forecasts the changes that can take place all around the world for the duration of the twenty-first century. For instance, China will disintegrate into pieces and its role as a growing power will weaken (Friedman and Myers 2010). It seems like this his prediction nothing else but just a myth as China is growing economically as an emerging world power and US already perceives it as a threat.

\section{Pak-USA relations}

Pakistan has diverse and complex relations with the US as it needed an alignment to deter the Indian threat on its eastern border and Afghanistan claims on its Western border. Being a newly born state it always depended on the US for economic development and security. The US administration found Pakistan and its geographical location significant for the containment of the USSR and finally they got this task from Islamabad and started to fight against the USSR in Afghanistan. Washington always comprehends Pakistan as a client state and builds relations not on the bilateral level but master-slave level.

\section{Relations after independence}

August, 14, 1947 marks the day when Pakistan was created and the British subcontinent was divided into two separate and free countries: Pakistan and India, by the British Government. The areas with Muslim populations in large number which were also adjacent to each other, e.g., Sind, Punjab, Baluchistan, and Northwest Frontier Province (NWFP) and East Bengal or Eastern Pakistan, were declared a territory of Pakistan, giving her the population around seventy million where more than 90\% population was Muslim, while at the same time, there was a Hindu population in a very large number in India, where Muslims were just $15 \%$ of the whole population making them the second-largest minority group in India. There was a thousandmile of Indian territories between the Western and Eastern parts of Pakistan. India received the maximum number of infrastructure assets and much-developed areas by the British Empire, while Pakistan was given a small part of all resources, its areas having the least development and faced with inadequate administrative infrastructure (H. U. Khalid 2018a). The remainder of military assets were distributed between Pakistan and India once the Second World War ended. The major difficulties for Pakistan after its freedom were its safety, inadequate infrastructure, and insufficient pecuniary assets. This division (of two countries) based upon ethnicity 
and religion resulted in a large-scale migration of people from sides, mass killings, violence, and pillage. Both counties not only had differences over the distribution of resources but over the lands as well. The foremost clash between the two countries is over the state of Kashmir, which has resulted in a war in 1948 in which Pakistan captured one-third of the Kashmir state, and the rest is occupied by India.

Pakistan joined the British Commonwealth of Nations after its creation in 1947. Unlike the Indian policy of neutrality, which later brought it nearer to the Soviet Union instead of the US, Pakistan adopted a policy that was in favor of the West as Pakistan pursued sturdy coalitions to tackle India. In the beginning, Pakistan was presented with two options, either becomes an ally of the Soviet Union or the United States, and Pakistan chose an alliance with the US. (CSS Forum 2011) After gaining independence in 1947, Pakistan was in dire need of monetary support to run its infrastructure, for development and upgrading her army. No one knows when and why the Pakistani government decided to request military support from the United States. Once both countries gained independence, Pakistan decided to adopt a policy that would be in favor of the West while a leftist or a neutral foreign policy was adopted by the Indian Government. Pakistan was in search of durable support so that it could sway its larger and stouter neighbor India to abandon its demands for the land of Kashmir. The advancement in its infrastructure and upgrading of armed forces were also the reasons behind its desire to look for economic assistance. To get economic and military support, representatives were sent to the US government by Governor-General Muhammad Ali Jinnah after the establishment of Pakistan.

The policy of Pakistan centered on the situation that developed after the end of World War. Hostilities between the Soviet Union and the West had started and Pakistan accepted that for more dominance in the Middle East, the ingress to the Arabian Sea is the aim of the Soviet Union. As the neighbor of Afghanistan, Pakistan was in a position to forestall the plots of the Soviet Union and secondly, Pakistan was a Muslim state with no link and connection with the communists and hence was a likely partner of the US in the region. However, the party reigning over India at that time-Indian National Congress and its leaders were leaning more toward the principles of socialism and the Soviet Union. By becoming a friend of the US, Pakistan could provide a more secure position to the US to counter any expansionist designs of the Soviet Union in South Asia. Taking into consideration the approach of the US at that time, the rebuilding of Western Europe and Japan after the world war, the struggles for restraint in South East Asia and the Middle East were making the US less involved in the growing clashes of South Asia, while Pakistan only desired to build more strong ties with the US to acquire the upper hand in the case of conflicts with India.

For this purpose, Pakistan rejected the Soviet Union's invitation and went to the US instead, and from the start of the independence; Pakistan has joined the bandwagon of the US, because the US also needed Pakistan' for various known reasons. Only Pakistan could offer ground to the US in the region against any Soviet invasion in South Asia. (Javaid and Mushtaq 2014). Liaquat Ali Khan who was the first prime minister of Pakistan went to the US to hold a meeting with the then US President Harry S. Truman. It is also purported that a request was presented by the US 
President Truman to grant CIA the permission to construct a base in Pakistan to keep the actions of the Soviet Union under careful observation but Khan did not accept it.

During this time, the Pakistani officials who went to the US to obtain US economic assistance included Ayub Khan as commander-in-chief, Zafraullah Khan as foreign Minister, Ikramullah as foreign secretary, Ghulam Muhammad as finance minister, Iskandar Mirza as defense secretary and Mir Laiq Ali as a special envoy (Dawn 2012).

\section{During the Cold War and Post-Cold War}

Pakistan and the US relationship is reciprocal in nature and its existence is conditional to each other's support. The American administration relentlessly asks for Pakistan's support to oppose Communism. In 1947 when the subcontinent was divided to create two new states, the US was eager to have strong and equal mutual relations with both the newborn countries and expected them to safeguard the regional stability. But the Indian government gave a cold shoulder to the US and her attention diverted to Pakistan only. Pakistan warmly welcomed this gesture of friendship from the US for the "Strategic Alliance" since Pakistan was undergoing the toughest of times and was surrounded by insecurities from India and was afraid of the sub-continental reunion (Khan and Khalid 2018b). Pakistan and Russia had a completely counter-balancing strategy throughout the period of the Cold War. The struggle of Pakistan to stand firm against the Indian hegemony in the region and the US opposition against the former USSR bring US and Pakistan nearer and they became partners due to their motives. A "Mutual Defense Assistance Agreement" was endorsed by the US and Pakistan. Afterward, Pakistan joined a US-sponsored coalition, SEATO, the South East Asian Treaty Organization, the purpose of which was to quell communism. However, no pledge was made to Pakistan to take joint action in case of an attack on it from non-communist countries, especially India. Pakistan had no other choice so it chose to gradually take a shift from an impartial position to an outright coalition with the West.

The democratic system in the West had a great impact on the upper class of Pakistan, most of whom belonged to the feudal and establishment, who had received a Western education. This upper class had played a vital role in forging close ties with the US. The policy to achieve progress on the economic front using austerity measures and assistance from other countries and alliance with the US was supported by the civilian and military leadership, who were close to Governor-General Ghulam Mohammad in 1955. These were mostly those who had received their education in England, including his foremost companions as well, General Iskandar Mirza and Ayub Khan. Pakistan became a member of Baghdad Pact in 1955; which was later called CENTO, the Central Treaty Organization. The acuity started to grow among the Pakistani officials that the US failed to appreciate the efforts of Pakistan even though Pakistan was standing on the Western side formally and resolutely. A cooperation agreement was endorsed between 
Pakistan and the US in the year 1955, which made the US obliged to support Pakistan in case of any attack from any country, especially regional countries. Pakistan's unfriendly ties with India, Afghanistan, and financial situations were the reasons behind the participation of Pakistan in the Mutual Defense Assistance Agreement, SEATO, and CENTO.

But advancing the defense abilities of Pakistan to counter the Indian threat was the rudimentary aim behind those defense agreements for Pakistan's government. Building cordial and pleasant ties with the Muslim counties was another aim for Pakistan and becoming part of CENTO opened prospects for Pakistan to come nearer to Turkey and Iran. According to the US, Pakistan's growing interest in the Middle East was certainly a way to support the regional interests of the US. Till 1957, Pakistan had received extensive US assistance not only to improve its infrastructure and agriculture but the military as well, i.e., equipping Pakistan with extensive "military hardware, Patton tanks, artillery, helicopters, bombers, highlevel long-distance radars, frigates, and a Ghazi submarine" and the US help to build nuclear infrastructure. In exchange, permission was granted to the US to build a clandestine intelligence base at Badaber nearby Peshawar and conceal it by making it a "communication center" (Khan 2019). It was a site that was used to monitor China and specifically the Soviet Union through surveillance airplanes U-2 (Sunawar and Coutto 2018).

Starting from the 1960s, Pakistan had received arms from China and with her help, Pakistan advanced its arms industry and "nuclear weapons delivery systems" which armed Pakistan with "short and medium-range ballistic missiles, e.g., a chain of Shaheen Missiles". Presently, the advance weaponry mutually produced by China and Pakistan is in use of Pakistan's Air and Naval forces. Pakistan's Air Force includes a Chinese interceptor and advanced trainer aircraft, as well as an Airborne Early Warning and Control radar system used to detect aircraft. Pakistan is producing the JF-17 Thunder multi-role combat aircraft jointly with China. The K-8 Karakorum light attack aircraft was also coproduced. On the other hand, the ties between the US and Pakistan worsened and could not become feasible, viable, and continue for a longer period as anticipated by the US. Questions were raised after the 1965 Kashmir war as Pakistan's government perceived that no substantial help was delivered by the US and that attitude of the US was considered unjust, unscrupulous, and an impediment to practical and enduring ties between the two countries (Safdar Mehmood 2003). While the Muslim world extended its support to Pakistan, sanctions were imposed on Pakistan by the US throughout the war with India that took place in 1965.

Although Pakistan was denied martial apparatus and financial assistance by the US, India continued to receive military hardware and financial aid from the USSR to guarantee India's powers over Pakistan. The civilian and military establishment in Pakistan knew that detachment from the US is not entirely possible: they ultimately comprehended that absolute dependence on the West for help would not be in the favor of Pakistan. After reaching this logical conclusion, a plan of action was settled on by President Ayub that Pakistan would continue to be a part of the US-led coalition and in the meantime, would make Pakistan's relations with other major powers friendly, viable and stable. 
Pakistan, once a frontline ally in the Afghan war against the Soviets, became less important for the US after the departure of the Soviet army from Afghanistan in 1989 and was considered an unfriendly country of the US. As usual, the blame was put on the US for abandoning the state abruptly. In 1990, the financial and military assistance was stopped by the US. Thus, Pakistan chose to adhere to the nuclear option, making it another disagreement between the US and Pakistan and where the US desired the assistance of Pakistan to pursue its schemes and ambitions for the world but it led to the worsening of relations between the two countries (Shakoor 2001).

\section{Pak-US relations; Post 9/11-2001}

The world affairs took a different turn on September 11, 2001, as this incident had affected the world enormously. One day before, Pakistan and the US were not enjoying cordial relations but after this incident, a change took place on a global level and it was comprehensible that Pakistan is bound to act as a frontline state in this regard (Malik and Khan 2018). The revealed US treaties and meetings information established the fact that a decision was made to send a concrete message to Pakistan, Afghanistan and the Arab world to act together for the desired results. The main culprit for these attacks on the US was blamed to be Al-Qaeda.

After the 9/11 incident, Pakistan-US relations changed and both countries came closer again because of National Interests. At this time the US again needed Pakistan and now Pakistan has become the focal point of the US foreign policy because of the key role Pakistan is playing in WOT. Pakistan has become the frontline state in the war against terrorism because of many factors; first, its geographical location, second because of its religion Islam and mainly due to the pro-U. S alliance of Pakistan's President Pervez Musharraf in WOT. Pakistan had to choose whether to become part of the US war or not which would be fought in Afghanistan. This incident had a great impact on the world and required some action. Three resolutions: 1368, 1373, 1377, were passed by the United Nations Security Council in three days. It was the need of the hour to deal with this problem. Taliban and the US had enjoyed friendly relationships for a long time but it came to an end when the Taliban did not agree to hand over Osama Bin Laden to the US. And it was urged that Pakistan should convince the Taliban. Subsequently, there were two choices for Pakistan whether to break ties with the Taliban or face the consequences. Pakistan quickly received the advantages of becoming an ally of the US. The first step taken was the lifting of sanctions and receiving assistance guaranteed it as a fresh alliance between the US and Pakistan. The US President relinquished the "democracy sanctions" while exercising his powers under the Brownback-II Amendment, later on, the nuclear sanctions were lifted for a period of five years under the Ackerman amendment in 2004. The permission was granted to recommence the aid and military transactions by the US president and instantly approved to cancel a portion of the loan of Pakistan as well as delivered $\$ 600$ million of financial assistance. In the year 2002, the military and financial aid equaled $\$ 177$ million. The decision to provide Pakistan with $\$ 3$ million as financial and military aid was made by the Bush 
administration in 2003 (Ahmed and Kharal 2015). On the other hand, during the war, Pakistan granted permission to use its air space, shared intelligence information, and offered logistical support as well as the use of three airbases. On February 13, 2002, US President Bush called attention to the Pakistani decisive role in this war and acknowledged Pervez Musharraf for his efforts to counter-terrorism (Akram 2002). The US granted Pakistan the position of "non-NATO ally." All of this played a role in making the relations between Pakistan and the US normal again. Efforts were made by the Bush administration to make the government of President Musharraf strong.

US military and economic aid to Pakistan

\begin{tabular}{lll}
\hline Year & Military (USD in billions) & Economic (USD in billions) \\
\hline 2002 & 1.36 & 1.233 for 2002-2003 \\
2003 & 1.577 & \\
2004 & 1.200 & .338 \\
2005 & 1.313 & .539 \\
2006 & 1.260 & .567 \\
2007 & 1.115 & .507 \\
2008 & 1.435 & 1.366 \\
2009 & 1.689 & 1.409 \\
2010 & 1.232 & Known \\
2011 & 1.685 & 6.08 \\
Total & 11.740 & \\
\hline
\end{tabular}

US Department of defense statistics

The occurrence of 9/11 marked the beginning of a new epoch which made the involvement of the US in Afghanistan resolute and made Pakistan a unique country that could provide security and logistical assistance. This affair set a direction for Pakistan's foreign policy and Pakistan only had some hours to choose a side and Pakistan chose to side with the US.

\section{The China factor in Pak-US relations}

Beijing has a special status and importance in relations between Washington and Islamabad as both were competitive powers and Pakistan always attempted adjustments to achieve its objectives. It was Islamabad that brought both Beijing and Washington close to each other in the 1970s and started unprecedented relations. However, Washington was concerned about helping Pakistan secretly transferring its technology to China which is unethical and illegal under international law. 


\section{The collapse of USSR and rise of China}

The most critical incident of the twentieth century was the disintegration of the USSR (Meisels 2012). At that time China had introduced certain economic reforms and by the 1990s it started to grow when USSR was collapsing. The downfall of the Russian economy in 1989-98 is opposite to the rise of the Chinese economy after the introduction of the economic reforms in 1979. The successor states of the former USSR also failed to do well in the field of economy. The situation in the USSR was getting worse with GDP falling by approximately 50 percent from 1989. Investment dropped to almost zero. Earning disparity had also greatly increased so much so that nearly everyone faced a downfall in income and the death rates had ascended by about 50 percent (Popov 2007). The alliance between the US and Pakistan was also supported by China against the invasion of the Soviet Union in Afghanistan. When the Soviet Union collapsed, Pakistan had two international friends: China and the US.

\section{China's support for Pakistan}

Pakistan has always been supported by China in all spheres of life. In 1951, diplomatic relations between both the nations were established and Pakistan became the first Islamic and the after India second South Asian state to found diplomatic terms with China. Ever since there was no turning back for both the countries and they have remained strongest partners so far. Several foremost bilateral dealings over the years reveal the depth of their bond. During the wars of 1965 and 1971, China supported Pakistan against India. Besides, in 1979 China also encouraged the coalition among Islamabad and Washington against the attack of the USSR in Afghanistan. China in 1972 also barred Bangladesh from joining the United Nations by her maiden veto power use. Besides Cuba, the other United Nations member state to back China in the Tiananmen Square incident of 1989 was Pakistan. Also, Pakistan in 1971 contributed productively in a critical tour of American National Security Adviser Henry Kissinger to China. Both the states Pakistan and China take pleasure in strong collaboration in trade, education, culture, borders, and militaries, which means that Pakistan possesses an exceptional standing among several diplomatic allies of China (Lee 2016).

\section{China's human rights violations and the USA}

The issue of human rights has remained a bone of contention in China-American terms in the post-Cold War period to date. The factors of Taiwan, trade, and arms control are also there to spoil Sino-American relations but human rights issues are trickier to resolve (Qi 2005). The oppression and methodical violence on the 13 million Turk origin Muslims, including Kazakh tribes inhabiting northwestern Xinjiang region of China and Uyghur were noticeably intensified by the authorities. Public random incarceration, affliction, and exploitation of a range of confinement measures by the authorities aimed at curtailing everyday life. New laws and rules imposed 
by the government in Tibet have banned almost every conventional kind of social activity, for instance, the meditation done by spiritual people. The Sino-British Joint Declaration promised "a high degree of autonomy" to a region in Hong Kong in 2018, Hong Kong and the administration of China accelerated their efforts to usurp the rights of the freedom of speech and political involvement (Human rights watch 2018). Numerous human rights violations are there in China and the US is trying to highlight those issues as well mainly to defame China. But there is a need to have sincere efforts to protect human rights violations in any region without seeing their interests, as far as human rights are concerned.

\section{Washington's concerns and CPEC}

The US Secretary of Defense, James Mattis, has expressed illogical concerns on CPEC. He questioned the legality of the project because of the US concerns, the corridor passes through the so-called disputed territory. The geopolitical position of CPEC has worried the US who has been expressing her uneasiness regarding the Pakistan-China relations and the CPEC (Jaleel et al. 2019). The strategic significance of Pakistan due to its geographical surroundings is undeniable. Pakistan is surrounded by important states since Afghanistan lies in her north while the bounteous Gulf is in the south. The US keeps funding Pakistan through US aid that is stopped every time Pakistan refuses to accept the undue US commands over strategic affairs such as Afghanistan. Speaking the truth, the United States is panicked by losing her power to China in the Asian region (Rahim et al. 2018). However, domestic unrest in China in the form of troubled Xinjiang is in favor of the US hegemonic objectives, because this way China will remain occupied internally and won't be attentive to world politics. But the project of CPEC is anticipated to facilitate China in conquering the internal security dilemmas and Washington is afraid of the thought of a ferocious China. This undue horror has coerced the United States to respond antagonistically toward CPEC (Ahmad 2018).

\section{Washington-New Delhi alliance to contain China}

China is rising rapidly and the US is afraid of China's rise and it has begun started to make different strategies to contain China. The US is developing its relations with India which is also a growing economy. There was a historical US-Pakistan alliance, but Pakistan's close ties with China also compel the US to ally with India to restrain China. The relationship between India and the US has taken a fresh twist under the Modi administration, and a heartier and more vigorous bond is emerging between the two. The Indian government is revising its foreign policy in favor of the US-India national interest in the milieu of a strong alliance between Russia, China, and Pakistan. In early 2000, the bond between India and the US started getting stronger notably by signing the NSSP (the Next Steps in Strategic Partnership) and the civil nuclear agreement, and Defense Cooperation Framework Agreement in 2005. All these treaties were an indication of countless superior prospects for India in terms of US collaboration. In 2015, the replenishment of the Defense Cooperation 
Framework Agreement and the Joint Strategic Vision additionally fortified the alliance that was developed years back (Khan 2017a, b). Other numerous partnerships can be seen between US and India too, mainly to contain China (Gul et al. 2018).

\section{Beijing, Islamabad, and NSG entry}

NSG (Nuclear Suppliers Group) is an all-party export control management and is mainly comprised of a group of nuclear supplier states who are desirous of putting off any sort of nuclear propagation. There are more than 45 states including nuclear power countries and some other NPT states, who believe in administering the export of nuclear tools and expertise and material that can be used in producing more nuclear weapons. The NSG members are that are also part of the NPT; a Nuclear Non-Proliferation Treaty. Both India and Pakistan have requested to be members of NSG as both are nuclear power states. As per rules, India and Pakistan cannot join NSG, because they are not members of NPT. Still, the US has raised her voice in favor of India, because the US wants to raise India as a counterweight to China in this region and therefore has expressed her support for India to join NSG. Joining NSG will facilitate India to take advantage of international nuclear trade and enhance the nuclear power status of India and her access to the latest nuclear technology. To counter this situation, China has stepped forward in the support of Pakistan and has denounced the membership of India in NSG until or unless Pakistan is not made a part of it (Khan 2017a, b). China has always supported Pakistan to ward off discriminatory treatment of the US, India, and other countries.

\section{Repercussion for Pakistan}

Indo-US developed relations on mutual grounds and both claim to be the largest democratic states in the world in terms of size and ideals. History is a witness for the dilemma that faced Pakistan when New Delhi came close to Washington and avoided Pakistan. The US withdrawal from Afghanistan in 2014 also a phase that marked Pakistan on the verge of its relations with the US. During the US-Indo closeness Pakistan was put in isolation politically and economically and was blamed for the support of terrorism.

\section{Washington inclination to New-Delhi on outstanding issues}

The ties between India and the US have become healthier and stronger during the reign of Modi.

Against the backdrop of a closer alignment between Russia, China, and Pakistan, the US-India national interest-driven Indian foreign policy is seen as a necessary step by the Modi's government. At the start of the twenty-first century, the actions that indicated grander circumstances for India were US assistance in various fields 
particularly the civil nuclear agreement, afterward the strategic partnership (NSSP) and Defense Cooperation Framework Agreement between India and the US in 2005. The Defense Cooperation Framework Agreement was renewed after some time and the Joint Strategic Vision was endorsed in 2015 which made the achievements, obtained so far, stronger. While Prime Minister Modi was on a visit to the US for three days in 2016, he not only met with Obama, the former American President, but also addressed the American Congress and concluded joint energy, security, and trade contracts. Three regions under which the Indo-US relations have sought convergence and gained momentum are Asia Pacific, Afghanistan, and Africa. The peace and security relationship further divide into defense, counter-terrorism, and political consultations. The two countries have pledged to help each other in various fields, e.g., making India a member of Multi-lateral export control regimes, taking a dynamic role in Afghanistan, warding off the fears of terrorism and the cooperation to prevent the nuclear proliferation. These are the major areas where both countries share similar interests which have contributed toward more steady relations and their strategic partnership keeps on growing irrespective of any party's government in these two countries (Khan 2017a, b).

The US wants India to be part of NSG to promote India as well as to fulfill her national objectives. In contrast to that, China has always been condemned by the US due to the human rights violations under a Socialist government but the same considerate US administration seals the lips on the Hindu atrocities on the minorities in India. This discriminatory approach reveals the US dual policy. The US National Security Adviser John Bolton after the Pulwama attack in occupied Kashmir expressed his wish and support to India in bringing the perpetrators of the fatal car bombing to justice. This incident further soured Pakistan and India terms since Jaish-e-Mohammad, a Pakistan-based militant group, has proclaimed the liability for the attack on the Indian military convoy in which 44 paramilitary policemen were exterminated. And again India's right to self-protection against cross-border

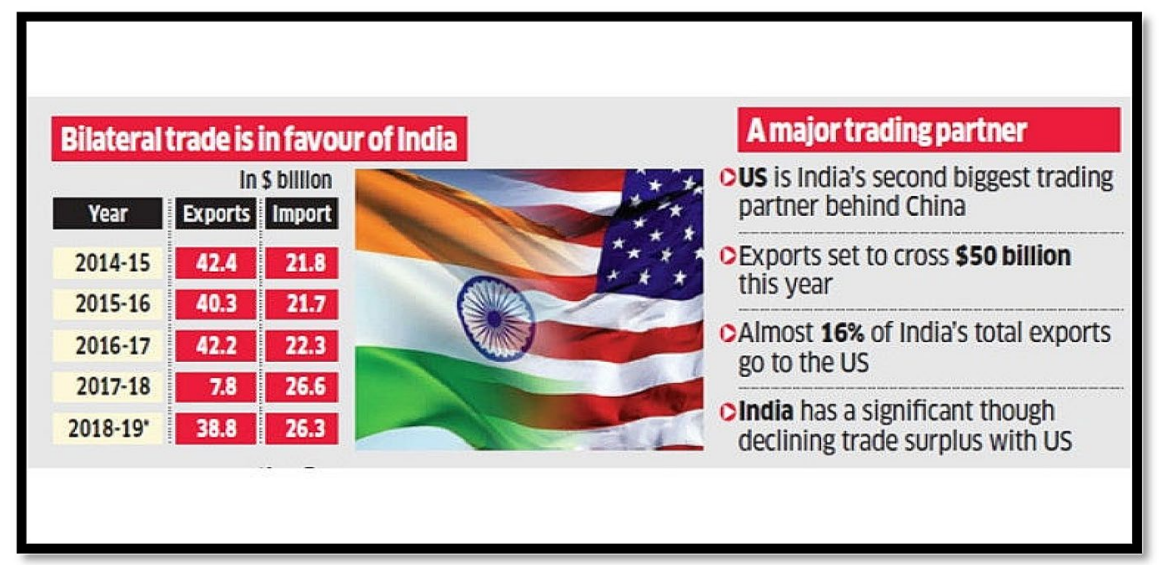

Fig. 2 Source: https://www.dkoding.in/newsline/free-trade-us-indias-opportunity-chinas/

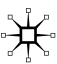


terrorism was supported by the US, the Indian Foreign Ministry declared in an account (Reuters 2019).

On the other hand, Pakistan also reduces its military dependence on the US, and China is taking the place of the US in this regard. Pakistan decided to use JF-17 fighter jets instead of F-16 s as both China and Pakistan co-produce it and it is gradually coming to the level of F-16. Due to US sanctions, Pakistan has started to obtain Chinese-made weapons instead of the US ones or the ones locally produced by Pakistan with the help of China while distrusting the growing close ties between India and the US at the same time. According to a research fellow, Harrison Akin, working at the Howard H Baker Jr. Centre for Public Policy at the University of Tennessee, the actions of Trump's Government will only bring Pakistan closer to China particularly when Pakistan is now receiving Chinese weapons instead of US ones (Iqbal 2018). Pakistan is extremely indebted to China at present. Pakistan now looks up to China when it comes to armaments, financial assistance to save Pakistan's economy, and the backing of China on the international and diplomatic front while the US tilted toward India (Sareen 2019).

In the past decade, US and India have developed better ties during the reigns of Republican and Democratic governments in America (Fig. 2). Bilateral trade between them is now $\$ 115$ billion, foreign direct investment is rising and both share similar regional outlook which is a reason behind mutual security interests (Shahzad 2018).

Analysis of Pak-China Bonhomie and repercussions for Pak-USA relations:

If history is a guide, then the relations between the USA and Pakistan have always been topsy-turvy and always characterized as transactional in nature. In the Cold War era (1945-1991), the USA and other western countries needed Pakistan to execute its containment strategies directed against the communist USSR. Decades later, when Pakistan was left in the lurch by the USA, the latter again approached Pakistan to execute the Afghanistan war. After the war was ended, Pakistan was again slapped with every kind of conceivable sanctions. The dawn of the twenty-first century and the subsequent development which brought terrorism into sharp focus, Pakistan was again the center of attention for the policymakers in the USA for it had a geographical location in such a way which had an added advantage over any other country. The USA announced its Af-Pak policy in 2009. The announcement of the policy was also the indication that the USA was looking for other alternatives to deal with its war on terror in Afghanistan. The USA started its rant of "do more" against Pakistan since then. In recent years, when the USA was looking for alternatives in Afghanistan, it again approached Pakistan to help it thrash out the problems in an amicable manner. Hence, the whole relations, in its historical perspective, reveal that the relations always were transactional: each side believed that the other side is culpable of dereliction. The trust deficit continues even now.

However, Pakistan never thought of putting all its eggs in a single basket. The debacle of 1971 revealed that it would be better for Pakistan to formulate its policy based on bilateralism. It was during the era of Zulfiqar Ali Bhutto when he aligned foreign policy toward China because of his socialist credentials. The subsequent events dawn upon Pakistan that it would be better to establish relations with rising economic power. The thriving economy of China portends well for Pakistan's 
relations as china always supported Pakistan thought thick or thin. In recent years, China has embarked upon the BRI which aims to integrate the Chinese economy to the world economies. Thought it has received many criticisms from the opponents of china, it has been considered a trigger for rising china (Haider and Waqar 2019). Pakistan is fully integrated into the project through CPEC. The CPEC project will further cement the relations between the two countries. However, the growing bonhomie has been received with skepticism in the USA. The growing relations have the following repercussions for the relations involving Pakistan and the USA (Ishaque et al. 2018).

\section{The Kashmir issue}

The government of China has always supported Pakistan through thick and thin over major policy issues including the issue of Kashmir (Saddiqa and Yousafzai 2019). China recognizes the claims of Pakistan. However, the valley of Kashmir has been stripped of its special status in August 2019 by removing article 370 and 35A from the constitution. Such developments have exacerbated Pakistan's challenges regarding the Kashmir issue. The bonhomie created between China and Pakistan and the resultant backing Pakistan receives from China will allow the USA to exploit the situation albeit the Trump administration has announced mediation. The USA could be easily played in the hand of the Indian government to make them realize that Kashmir is an integral part of the Indian Territory. The defense secretary of the USA once also criticized the Chinese project going through Gilgit Baltistan. Hence, the bonhomie between China and Pakistan does portent a situation where the USA will openly support India's claim (Khalid 2019).

\section{The Nuclear program of Pakistan}

The nuclear program of Pakistan always had been in the spotlight. Pakistan benefitted from the "atom for peace" intuitive spearheaded by the Eisenhower administration. When one looks at the nuclear program of Pakistan, one thing becomes conspicuous: The USA supported Pakistan nuclear program when the former needed its support. Pakistan was lent such support when the Cold War was in its climax. Secondly, the nuclear sanctions under the Symington amendment were removed, once Pakistan joined and co-opted the USA for the fight against the USSR in 1979. Thirdly, a kind of relaxation was given when Pakistan joined the War on terror. However, the nuclear program in again in the spotlight due to the irrelevance of Pakistan for the USA and changing priorities of the latter. This is the reason that the USA has extended the civil nuclear deal to India but not to Pakistan. The USA has also supported India's entry into Nuclear Supplier Groups (NSG) but the same has been forestalled by China's efforts. Hence, the presence of China in the backyard of Pakistan and the support it extends to Pakistan will create fissures in the relation between China and the USA. At the time when Pakistan is faced with security threats of unprecedented proportions, such kind of development does not bode well for the social situation in the country (Murad et al. 2019). 


\section{Economic support}

Pakistan recorded a negative growth rate of the economy in the fiscal year of 2019. These situations have been exacerbated by the newly emerging coronavirus. Initially, Pakistan received support from the International Final Institutions like the IMF and the World Bank. The negotiation with the IMF involved many ups and downs. Pakistan was suspicious that receiving such support from the IMF will allow Pakistan to the repayment of debt to China. The USA accused China of "debt diplomacy" which the latter claims are doing in various ways. The emerging situation and rising China will create an environment where the support of the USA would be instrumental to bolster Pakistan dwindling foreign exchange reserves. In the foreseeable, Pakistan will face hard negation with the IFI's due to the lack of USA support.

\section{The increasing role of India in the region}

The rise of China is coinciding with the fall of the erstwhile USSR. Once the USA dispense with one superpower, another economic superpower was emerging. From then on, the USA started to contemplate on various initiatives to contain the rise of China. For that very purpose, India was co-opted. The support India is receiving in the form of the civil nuclear deal and the support In NSG reveals those things. Similarly, the policy announced by USA president Donald Trump as "South Asian policy" also envisaged a greater role for India in Afghanistan and region at large. Hence, China's rise could be contained through cooperation with India (Hussain et al. 2018).

\section{USA-India nexus for Pakistan's isolation}

Presently China is posing a massive threat to the US. Her Western allies and India and are striving hard to contain China, while Pakistan is unconditionally supporting China by being the closest ally to her. This precarious situation makes both India-US and Pakistan-China rivals to each other by putting them both on two clashing ends. India backs all the policies of the US to endorse her purposes, whereas Pakistan is opposing them due to her interests (Chaudary 2016). The US wants to contain China and India is desirous of containing Pakistan and because of the China-Pakistan alliance, US-India also wants to contain Pakistan which is an ally of China. India and US both have their interests in the region and this compels both of them to cooperate and to make an alliance against China and Pakistan.

\section{Conclusion}

World Politics has undergone tremendous changes in the twenty-first century especially post $9 / 11$ that reshaped and redesigned the alliance system by making friends into foes and enemies into an ally. Like other regions, South Asia also has seen changes in Cold War relationships, and both major actors of the region India and 
Pakistan have joined the opposite club in regional and global politics. The malign and slandering approach of the Trump administration to pressurize Pakistan is also adding fuel to the fire. India is profoundly benefitting herself from the strained relations between the US and Pakistan. The US and her western allies are leaving no stone unturned to prevent China from becoming the top economic and military power and concurrently the US does not want Russia to resurface as an impending threat to her status of the sole superpower. To ensure her aspirations, the US is incessantly supporting India to give a tough time to China and Pakistan both and balance to the rapidly increasing Chinese authority in the region and globally. India has become the closest strategic collaborator of the US and the west due to its strategic concerns in South East Asia (Ashraf 2018). So the rise of China was the main threat for the US and the rise of China was the only reason the US tilted toward India and which eventually hurt Pak-US relations.

As China's powers keep on increasing so do its interests and desires. It is not an indication that China has already preset its objectives and they are firmly established. The motives, tenets, the course of action chosen to adopt in the political arena, influence and the competencies dictate the actions a country uses in international relations. There are a large number of goals where prodigious influence can be used enormously. History tells us that China will always remain hungry for more power despite gaining it already and it will attempt to turn the global atmosphere the way it benefits China. However, the grander abilities of China will not be the only one deciding the essence of its hunger for power and the resources that will satisfy her but the social groups governing China will also be a part of devising policies (ART 2010).

It can be concluded from the latest articles in the media and the views expressed by US president Trump that Pakistan will be less important to the US. The ties between them will remain intact but weak, though, in case of the region facing an unforeseen incident, the US may pay attention to Pakistan again. Current developments point out a troubled relationship between Pakistan and the US and the reason is the differences in the way these two states take the struggles and fight against terrorism and belligerent groups. Under this circumstance, the way President Trump has been expressing his views is an indication of what does he feel about the nuclear weapons of Pakistan. Asking the assistance of India to deal with the problem, and talking about the "semi-unstable nuclear-armed Pakistan" in one of his interviews while he was campaigning to win elections is a clear manifestation of his feelings. It is noteworthy that the US will carry on with its previous policies such as increasing strategic partnership with India to restrain China, force Pakistan to take more action against all terrorists and attempt to obtain the support of Pakistan for boosting of the peace process in Afghanistan (Akram 2017). Pakistan has Russia and China both as its support, and they would even like to accelerate relations even more. But Pakistan should learn from its history and should not get on the bandwagon with China or Russia as they did with the US in the past; rather they should adopt a balanced approach in their foreign policy.

The relations between China and Pakistan exhibit a strong bond of mutual respect in national, strategic, and economic interests. The relations have been on an even 
keel since diplomatic relations were established. However, the strengthening of relations between the two countries and its repercussions for the relationship involving both Pakistan and the USA cannot be ruled out. Though Pakistan acted as a conduit for China and America détentes, the changing dynamic of relations will have its impact on different areas of foreign policy. It will impact Pakistan's stance over the issue of Kashmir. Pakistan's nuclear program will come under severe examination. At least since the 1980s, Pakistan has relied upon the USA sponsored International Financial Institution, i.e., IMF. In such a situation, Pakistan will be faced with difficulties to get bailout packages. The most important aspect is the role India is likely to play after the relations are improved between the two countries. Therefore, for the relations to be established on even keel and Pakistan to maintain a balance between the two countries, there must be a constructive approach rather than resorting to putting all eggs in the Chinese basket.

\section{Compliance with ethical standards}

Conflict of interest The corresponding author states that there is no conflict of interest.

\section{Appendix}

\begin{tabular}{lllll}
\hline Year of delivery & Weapon designation & Type & Receiving service & Quantity \\
\hline 1981 & Hia-Ying-2 & Ship to Ship Missile & Navy & 8 \\
1981 & Hia-Ying-2 & Launcher & Navy & 4 \\
1981 & Hegu class & Fast attach craft & Navy & 4 \\
$1981-82$ & T-60 & Tank & Navy & 4 \\
$1982-83$ & Type 82 122 & MRL & Army & 50 \\
$1983-84$ & A-5C Fan Tan & Fighter/ground attack aircraft & Air Force & 52 \\
1984 & Hia-Ying-2 & Ship to Ship Missile & Navy & 16 \\
1984 & Hia-Ying-2 & Launcher & Navy & 4 \\
1984 & Huangfen Class & First Attack Craft & Navy & 4 \\
$1986-7$ & F-7M Air Guard & Fighter Aircraft & Air Force & 20 \\
NA & A-5 A Fan Tan & Fighter/Ground attack aircrafts & Air Force & 9.8 \\
1985 & HQ-2B & Surface to Air Missile & Navy & 20 \\
1985 & HQ-2B & Surface to Air Missile & Navy & 2 \\
1987 & Fuking Class & Support Ship & Navy & 1 \\
NA & K-8 & Jet Trainer & Air Force & 6 \\
$1989-90$ & Type P58A & Patrol Craft & Navy & 4 \\
$1989-91$ & T-69 & Tank & Army & 275 \\
$1989-91$ & Anza (Under license) & Portable SAM & Army & 350 \\
$1990-91$ & F-7P Air Guard & Fighter Aircraft & Air Force & 80 \\
1992 & F-7M Air Guard & Fighter Aircraft & Air Force & 40 \\
$1990-92$ & Red Arrow-8 & Anti-Tank Missile & Army & 150 \\
\hline & & & &
\end{tabular}




\begin{tabular}{lllll}
\hline Year of delivery & Weapon designation & Type & Receiving service & Quantity \\
\hline $1991-92$ & T-69 11 & Tank & Army & 160 \\
1991 & M-11 & Ballistic Missile & Army & 55 \\
1991 & M-11 launcher & Ballistic Missile Launcher & Army & 20 \\
1992 & F-7P Sky Bolt & Fighter Aircraft & Air Force & 40 \\
\hline
\end{tabular}

\section{References}

Ahmad, M. 2018. Efforts needed to counter anti-CPEC propaganda. http://www.globaltimes.cn/conte nt/1115527.shtml. Accessed 9 June 2019.

Ahmed, Z., and A. Kharal. 2015. Pak-US relations post 9/11: Impact of aid, irritants and regimes in Pakistan (2001-2013). Journal of Politics and International Studies 1: 14-23.

Akram, S. 2017. Presidential change in the US: Implications for Pakistan. ISSI 3: 115-123.

Akram, Z. 2002. Pakistani-U.S. relations after 9/11: A Pakistani perspective. Georgetown Journal of International Affairs 3: 115-123.

Alliance and the Indo-US. 2016. The Indo-US alliance and its implications for Pakistan. https://defen ce.pk/pdf/threads/the-indo-us-allianceand-its-implications-for-pakistan.427277/. Accessed 17 Dec 2017.

Art, R.J. 2010. The United States and the Rise of China: Implications for the Long Haul. Political Science Quarterly 125: 359-391.

Ashraf, M.M. 2018. US-India nexus threat to peace. https://www.pakistantoday.com.pk/2018/07/11/usindia-nexus-threat-to-peace/. Accessed 12 June 2019.

Chaudary, S. 2016. Why the US supports India. https://www.thenews.com.pk/print/130262-Why-the-USsupports-India. Accessed 11 June 2019.

China Power. (2020). What does China really spend on its military? https://chinapower.csis.org/militaryspending/. Accessed 8 June 2019.

CNN. 2019. China's military is going from strength to strength under Xi Jinping. Retrieved from CBS 6 tv: https://localtvwtvr.wordpress.com/2019/03/04/chinas-military-is-going-from-strength-to-stren gth-under-xi-jinping/.

CSS Forum. 2011. History of Pakistan-U.S relations. CSS Forum. 07 19. http://www.cssforum.com.pk/ css-compulsory-subjects/current-affairs/51821-history-pak-us-relations.html. Accessed 7 July 2019.

Dawn. 2012. Dawn. Timeline: History of US-Pakistan relations.

Dimensions, New. 2000. New Dimensions in the Indo-U.S. Relations. India-US relations and bilateral issues, July 23, IV ed.: 2 of 33. http://shodhganga.inflibnet.ac.in/bitstream/10603/52023/10/10_ chapter\%204.pdf.

Friedman, G., and J. Myers. 2010. The next hundred years: A Forecast for the 21st century. Anchor.

Gul, S., S. Umer, and M.S. Malik. 2018. China's Belt and Road Initiative (BRI): Debt quagmire or a ridge rope for struggling economies. Global Economic Review III (I): 62-70. https://doi.org/10.31703/ ger.2018(iii-i).07.

Haider, S.I., and A. Waqar. 2019. Projection of CPEC in Print Media of Pakistan from 2014-2019. Global Strategic and Security Studies Review V (I): 45-64.

Human rights watch. 2018. China events of 2018. https://www.hrw.org/world-report/2019/country-chapt ers/china-and-tibet. Accessed 10 June 2019.

Hussain, M., S.U. Jalal, and M. Bilal. 2018. Indo-US Strategic partnership and regional politics. Global Regional Review III (I): 1-16. https://doi.org/10.31703/grr.2018(iii-i).01.

India US. 2017. India, US initiate new chapter in bilateral counter-terrorism cooperation; Move could help New Delhi bypass Chinese manoeuvres. Edited by FP editors. http://www.firstpost. com/india/india-us-initiate-new-chapter-in-bilateral-counter-terrorism-cooperation-move-could -help-new-delhi-bypass-chinese-manoeuvres-4255251.html. Accessed 30 Dec 2017.

Iqbal, A. 2018. Pakistan reducing dependence on U.S arms.FT reports. Dawn. https://www.dawn. com/news/1402479. Accessed 7 July 2019. 
Ishaque, W., A. Ullah, and I. Khalid. 2018. Chinese dream and prospect of harmonious world policy: Drawing lessons for Pakistan. Global Political Review III (II): 40-51. https://doi.org/10.31703/ gpr.2018(iii-ii).05.

Jaleel, S., N. Talha, and Z. Shah. 2019. CPEC and regional integration. Global Regional Review IV (IV): 19-28. https://doi.org/10.31703/grr.2019(iv-iv).03.

Javaid, U., and I. Mushtaq. 2014. Historical perspective of Pakistan USA relations; lessons for Pakistan. South Asian Studies 29: 291-304.

Khan, H.U., and I. Khalid. 2018a. New Delhi response to Beijing's BRI project: A Lucid connection with Chinese "String of Pearls". Journal of Political Studies 25: 244-284.

Khan, H.U., and I. Khalid. 2018b. Indian cold start doctrine: Pakistan's policy response. Journal of the Research Society of Pakistan 55 (1): 325-341.

Khalid, I., and H.U. Khan. 2018a. CPEC and federalism: An analysis. Journal of Political Studies 25: 195-199.

Khalid, I., and H.U. Khan. 2018b. New delhi response to beijing "BRI" project: A lucid connection with chinese "String of Pearls". Journal of Political Studies 25 (1): 243-254.

Khalid, I. 2019. Sino-Russian Stance on Kashmir issue. Global Strategic and Security Studies Review $\mathrm{V}(\mathrm{I}): 47-56$.

Khan, H.U. 2019. Regional security threats to CPEC: A strategic overview. Journal of the Research Society of Pakistan 56: 184-187.

Khan, M. 2017a. Growing India-US strategic cooperation: An analysis. Institute of strategic studies, Islamabad 37: 97-117.

Khan, Mahrukh. 2017b. Growing India-US strategic cooperation: An analysis. Strategic Studies 37: 97-117.

Lee, J., and Tse-He. 2007. The rise of China: An introduction. Indian Journal of Asian Affairs 20: $1-4$.

Lee, R. 2016. The strategic importance of Chinese-Pakistani Relations. http://studies.aljazeera.net/ en/reports/2016/08/strategic-importance-chinese-pakistani-relations-160803101555719.html. Accessed 11 June 2019.

Malik, M.S., and H.U. Khan. 2018. Regional security threats to Pakistan: A critical review. Pakistan Journal of History and Culture 39: 162-167.

McCarthy, N. (2020). The Biggest Military Budgets As A Share Of GDP In 2019 [Infographic]. Retrieved from forbes: https://www.forbes.com/sites/niallmccarthy/2020/04/27/the-biggest-military-budgetsas-a-share-of-gdp-in-2019-infographic/\#5f9f200a37f1.

Mehmood, S. 2003. Pakistan: Political roots and development 1947-1999. Oxford: Oxford University Press.

Meisels, Greer. 2012. What China learned from the Soviet Union's Fall. https://thediploma t.com/2012/07/what-china-learned-from-the-soviet-unions-fall/. Accessed 11 June 2019.

Murad, M., M.R. Kolachi, and U. Ishfaq. 2019. Nuclear Suppliers Group (NSG) membership: The case of India and Pakistan. Global Political Review III (II): 31-39. https://doi.org/10.31703/ gpr.2018(iii-ii).04.

Ohashi, Hideo. 2019. The Belt and Road Initiative (BRI) in the context of China's opening-up policy. Journal of Contemporary East Asia Studies 7: 85-103.

Popov, Vladimir. 2007. China's rise, Russia's fall: Medium term perspective. Transformation, Integration and Globalization Economic Research 99: 1-32.

Qi, Z. 2005. Conflicts over human rights between China and the US, 105-124. Baltimore: The Johns Hopkins University Press.

Rahim, N., A.M. Khan, and M. Muzaffar. 2018. Problems and prospects of CPEC for economic development and regional integration. Global Economic Review III (I): 21-30. https://doi. org/10.31703/ger.2018(iii-i).03.

Reuters. 2019. U.S. adviser Bolton promises India support after Kashmir attack. https://www.reute rs.com/article/us-india-kashmir-usa/u-s-adviser-bolton-promises-india-support-after-kashmir-attac k-idUSKCN1Q504T. Accessed 10 June 2019.

Saddiqa, A., and F. Yousafzai. 2019. A comparative study of the Kashmir conflict coverage in Pakistani and indian press. Global Social Sciences Review IV (III): 1-9. https://doi.org/10.31703/ gssr.2019(IV-III).01.

Sareen, S. 2019. For Pakistan, China is the new America. Observer Research Foundation. https://www. orfonline.org/expert-speak/pakistan-china-new-america-48305/. Accessed 7 July 2019.

Shahzad, M.W. 2018. Indo-US relations: Implications for Pakistan. Open Journal of Social Sciences. 
Shakoor, F. 2001. Pakistan-US relations: An interpretation. Pakistan Institute of International Affairs 54: 19-32.

Statista. 2019. China: Growth rate of real gross domestic product (GDP) from 2011 to 2023. Statista. https://www.statista.com/statistics/263616/gross-domestic-product-gdp-growth-rate-in-china/. Accessed 7 June 2019.

Sunawar, L., and T. Coutto. 2018. U.S. Pakistan relations during the cold war. The Journal of International Relations, Peace Studies, and Development 1: 1-11.

Vijayalakshmi, K.P., A. Kumar, S. Gupta, and S. Chandrashekar. 2017. Changing contours of Indo-US relations. Bangalore, India: National Institute of Advanced Studies Indian Institute of Science Campus Bangalore 560 012, 310. 2017. http://eprints.nias.res.in/75/2/2006_February_Changing_Conto urs_of_Indo-US_Relations.pdf. Accessed 16 Dec 2017.

Xie, Zhihai. 2011. The rise of China and its growing role in international organizations. ICCS Journal of Modern Chinese Studies 4: 85-96.

Zhang, Y., and G. Austin. 2013. Power and responsibility in Chinese foreign policy. Canberra: ANU Press.

Zhu, T. 2001. Nationalism and Chinese Foreign policy. The China Review 1: 1-27.

Zohra, F. 2018. How did China become the world's second economic power? Rising powers in global governance. http://risingpowersproject.com/how-did-china-become-the-worlds-second-economicpower/. Accessed 7 June 2019.

Publisher's Note Springer Nature remains neutral with regard to jurisdictional claims in published maps and institutional affiliations. 